\title{
Use of industrial waste concrete from steel manufacturing for blastholes casing in open pit mining
}

\author{
Elena Korneyeva*, Viktor Korneyev, and Petr Korneyev \\ Siberian State Industrial University, Novokuznetsk, 654000, Russia
}

\begin{abstract}
The article proposes to use grouting mixtures from industrial waste of steel manufacturing for casing blastholes. Its properties, defined in the course of laboratory studies, are given. One of the main features of the proposed casing technology is the production of pipes directly in the hole using a cylindrical formwork moving along the hole.
\end{abstract}

\section{Introduction}

The Russian Federation is one of the world leaders in coal production and export. Coal mining is carried out both by open and underground methods. Among the coal-mining regions, the most powerful supplier of coal is the Kuznetsk coal basin, where more than half $(56 \%)$ of all mined coal in Russia and $71 \%$ of coking coal are extracted [1]. Currently, there are 47 mines and 31 open-pit mines on Kuzbass territory. About $40 \%$ of the coal obtained from the Kuznetsk coal basin is consumed in the Kemerovo region itself, and $60 \%$ is transported to other regions of Russia for export [2].

During the development of coal deposits by the open method, approximately 500 thousand $\mathrm{m}^{3}$ of rock mass is blasted at a time. The preparation of such an explosive block is carried out within 1.5-2 months. Stemming and loading requires another week of time [3]. Thus, the holes are drilled about two or more months in advance before explosion and a set of measures is required to maintain them. One of the most important tasks in this case is to prevent sloughing of the borehole using casing pipes. The promising materials for their manufacturing are industrial waste formed at the enterprises in the region.

\section{Steelmaking slags and their properties}

Comprehensive processing of industrial wastes from fuel-and-power sector of Kuzbass and the production of building composite mixtures of various strength, density and water resistance classes from them is the fundamental concept of modern building materials science. Industrial waste is a valuable source of mineral raw materials [4]. A significant part of the solid mineral waste in Kuzbass is steelmaking slag generated and accumulated in large quantities at the largest metallurgical enterprises of full production cycle, EVRAZ

\footnotetext{
* Corresponding author: hellen-box-8@ya.ru
} 
United West Siberian Metallurgical Plant OJSC, which covers a significant part of the country's demand for metal. Their further intensive replenishment poses a serious environmental hazard for the region.

The physical and mechanical properties and composition of slags depends on the mineral resource base, represented by iron ore deposits of the Altai-Sayan folded region and the Angara-Ilimsky iron ore region (ores with magnesian waste rock and a high content of $\mathrm{Al}_{2} \mathrm{O}_{3}$ ), Salair limestones, dolomites of Gornaya Shoria and quartzites of Antonovsky mine.

Steelmaking slags are silicate systems similar in chemical composition to Portland cement (calcium oxide in them is bound to aluminosilicates and silicates). After activation (grinding, inclusion of activating additives), they acquire hydraulic activity and can be used to prepare the grouting mixture. Cement slurry are widely used in various construction works: soil strengthening in the foundations of buildings and structures, sides of foundation pits and landslide areas; construction of underground street crossings, interchanges of transport highways, collectors, tunnels, sub-surface metro, tailings dams and sludge collectors, as well as in hydraulic engineering $[5,6]$.

Use of cementless grouting mixtures with the application of secondary large-tonnage mineral resources and innovative energy-saving technologies can lead not only to resourcesaving, but also to a significant economic effect and meets the needs of modern engineering practice $[7,8]$.

\section{Results and discussion}

One of the possible applications of grouting mixtures based on steelmaking slags is their use in the manufacture of pipes for casing blastholes in open pits. This direction is especially important for Kuzbass, where significant volumes of technogenic deposits of steelmaking slags are concentrated and open pit coal mining is widely developed. Research on this problem is being carried out at Siberian State Industrial University.

The main requirement in the development of a cementless grouting composition for the manufacture of casing pipes is to obtain the specified quality characteristics.

As a result of calculation of the components ratio, the composition of the base grouting material was determined (Table 1).

Table 1. Composition of grouting material.

\begin{tabular}{|c|c|c|c|}
\hline \multicolumn{2}{|c|}{ Components of the composition } & \multirow{2}{*}{$\begin{array}{c}\text { Specific surface, } \\
\left.S_{s p} \text { (density, } \boldsymbol{\rho}\right)\end{array}$} & $\begin{array}{c}\text { Qty. } \\
\text { (\% wt.) }\end{array}$ \\
\hline \multirow{2}{*}{$\begin{array}{c}\text { Slag from } \\
\text { ZSMK OJSC }\end{array}$} & converter & \multirow{2}{*}{$S_{s p}=340 \mathrm{~m}^{2} / \mathrm{kg}$} & $48-50$ \\
& electric arc furnace & $33-35$ \\
\hline Burnt rock of mine dumps & $\rho=1.310 \mathrm{~g} / \mathrm{cm}^{3}$ & 10 \\
\hline \multicolumn{2}{|c|}{ Sludge } & the rest \\
\hline
\end{tabular}

The results of laboratory studies on defining the compressive strength and water resistance of grouting compositions with different component ratios are presented in Table 2. 
Table 2. Experimental results.

\begin{tabular}{|c|c|c|c|c|c|c|c|c|}
\hline \multirow{3}{*}{ 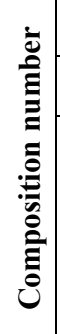 } & \multicolumn{4}{|c|}{ Material composition, $\%$, by weight } & \multicolumn{2}{|c|}{ Strength, MPa } & \multirow{3}{*}{ 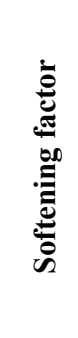 } & \multirow[b]{3}{*}{ Note } \\
\hline & \multicolumn{2}{|c|}{ slag } & \multirow[b]{2}{*}{ 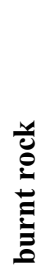 } & \multirow[b]{2}{*}{$\frac{\mathscr{B}}{\tilde{E}}$} & \multirow[b]{2}{*}{$\boldsymbol{R}_{d r y}$} & \multirow[b]{2}{*}{$\boldsymbol{R}_{w e t}$} & & \\
\hline & 远 & 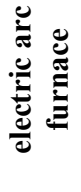 & & & & & & \\
\hline 1 & 40 & 45 & 3 & 12 & 4.22 & 3.05 & 0.72 & non-waterproof \\
\hline 2 & 45 & 40 & 5 & 10 & 8.43 & 6.12 & 0.72 & non-waterproof \\
\hline 3 & 48 & 35 & 9 & 8 & 10.15 & 8.39 & 0.83 & waterproof \\
\hline 4 & 49 & 34 & 10 & 7 & 11.18 & 9.56 & 0.85 & waterproof \\
\hline 5 & 50 & 33 & 11 & 6 & 9.56 & 7.84 & 0.82 & waterproof \\
\hline
\end{tabular}

Experiments have shown that with the addition of burnt rock in the amount of $<9 \%$, the softening coefficient decreases (the composition becomes non-waterproof), with the addition of $>11 \%$, the strength of the grouting stone decreases. The strength is insufficient and with the addition of sludge $>8 \%$, and $<6 \%$, the desired consistency of the mixture will not be achieved.

Thus, on the basis of experiments, the optimal composition of the grouting material is defined, which is water-resistant composition No. 4 with a compressive strength at the age of 28 days of $11.18 \mathrm{MPa}$ (M 100).

Since there are no recommendations for the selection of compositions and technology for their preparation with optimal characteristics for cementless grouting slurries from technogenic industrial raw materials, we used full-scale experiments.

The main requirement for the development of cementless grouting slurries is to obtain the specified quality characteristics for finished products in accordance with the Russian State Standard GOST 1581-96 Portland grouting cements. Technical conditions.

For the application of the obtained composition as a basic grouting material, its physical and mechanical properties were studied: rheological (grouting slurry) and strength (characteristics of the hardened stone). The analysis of the main properties of the grouting slurry and stone was carried out in accordance with GOST 26798.1-96 Grouting cements. Test methods (Table 3).

Table 3. Test results of the developed grouting material.

\begin{tabular}{|c|c|c|}
\hline Indicators & Test results & $\begin{array}{c}\text { Requirements in } \\
\text { accordance with GOST } \\
1581-96\end{array}$ \\
\hline Grinding fineness - specific surface area, $\mathrm{m}^{2} / \mathrm{kg}$ & 320 & not less than 270 \\
\hline Water sludge ratio & 0.5 & - \\
\hline Density of the solution, $\mathrm{kg} / \mathrm{m}^{2}$ & 1960 & - \\
\hline Density of stone, $\mathrm{kg} / \mathrm{m}^{2}$ & 2000 & not less than 2.7 \\
\hline Flexural strength at the age of 2 days, MPa & $2.79-3.98$ & - \\
\hline Compressive strength at the age of 2 days, MPa & $5.22-5.68$ & not more than 8,7 \\
\hline Water separation, $\mathrm{ml}$ & $<1$ & not less than 90 \\
\hline Thickening time to a consistency of $30 \mathrm{Vs} ., \mathrm{min}$. & $1200-1440$ &
\end{tabular}




\section{Conclusion}

The results of the experiments showed that the developed grouting material on an inorganic basis (from secondary mineral resources) as a result of complex physical and chemical processes [9] turns into a grouting stone, and meets the basic requirements of GOST 158196. No shrinkage or cracks during hardening are observed. For the developed composition patent "Grouting slurry" was received [10].

The resulting grouting slurry can be used in the manufacture of pipes for casing blast holes in open pits. A characteristic of this technology is the production of pipes directly in the well using a cylindrical formwork moving along the hole.

\section{References}

1. I.G. Tarazanov, D.A. Gubanov, Ugol, 12, 31-43 (2020)

2. Training center: General information about the coal industry http://www.ukkbel.ru

3. V.G. Lukyanov, V.I. Komashchenko, V.A. Shmurygin, Blasting operations (Publishing house of TPU, Tomsk, 2008)

4. S.V. Fedosov, Yu.A. Shchepochkin, et al., Secondary material resources for the construction industry (IVGPU, Ivanovo, 2017)

5. A.N. Grishin, A.I. Panchenko, et al., Bulletin of MGSU. Construction and Architecture, 11(110) (2017)

6. A.I. Kharchenko, V.A. Alekseev, et al., Vestnik MGSU. Construction and Architecture, 6 (2019)

7. V.D. Oreshkin, Building Materials, 8, 55-63 (2017)

8. T.Z. Lygin, V.P. Luzin, A.V. Kornilov, Izvestia KSUAE, 4, 303-313 (2017)

9. E.V. Korneeva, G.I. Berdov, Global Science Potential, 9, 66 (2016)

10. E.V. Korneeva, Patent 2642736 RF, Bulletin, 3 (2018) 